\title{
Influence of Recycled Aggregates on the Mechanical Properties of Synthetic Fibers-Reinforced Masonry Mortars
}

\author{
Alberto Morón ${ }^{1}$, Daniel Ferrández ${ }^{1}$, Pablo Saiz ${ }^{2}$ D, Gabriela Vega ${ }^{3}$ and Carlos Morón ${ }^{1, * \mathbb{D}}$ \\ 1 Departamento de Tecnología de la Edificación, Escuela Técnica Superior de Edificación, \\ Universidad Politécnica de Madrid, 28040 Madrid, Spain; amoroncsb@gmail.com (A.M.); \\ daniel.fvega@upm.es (D.F.) \\ 2 Departamento de Economía Financiera, Contabilidad e Idioma Moderno, Campus de Vicálvaro, \\ Universidad Rey Juan Carlos, 28032 Madrid, Spain; pablo.saiz@urjc.es \\ 3 Facultad de Arquitectura y Urbanismo, Universidad de Guayaquil, Guayaquil 090514, Ecuador; \\ gabriela.vegag@ug.edu.ec \\ * Correspondence: carlos.moron@upm.es; Tel.: +34-91-336-7583; Fax: +34-91-336-7637
}

Citation: Morón, A.; Ferrández, D.; Saiz, P.; Vega, G.; Morón, C. Influence of Recycled Aggregates on the

Mechanical Properties of Synthetic Fibers-Reinforced Masonry Mortars. Infrastructures 2021, 6, 84. https:/ / doi.org/10.3390/infrastructures6060084

Academic Editor:

Pedro Arias-Sánchez

Received: 29 April 2021

Accepted: 1 June 2021

Published: 4 June 2021

Publisher's Note: MDPI stays neutral with regard to jurisdictional claims in published maps and institutional affiliations.

Copyright: (C) 2021 by the authors Licensee MDPI, Basel, Switzerland. This article is an open access article distributed under the terms and conditions of the Creative Commons Attribution (CC BY) license (https:/ / creativecommons.org/licenses/by/ $4.0 /)$.

\begin{abstract}
The construction sector is one of the main consumers of raw materials and generates a high volume of waste within the European Union. The search for new materials that are more sustainable and respectful of the environment has become a challenge for countries with a high degree of industrialization. In this work, a study of the most relevant properties of masonry mortars made with recycled aggregates and reinforced with synthetic fibers was carried out. Three types of aggregates were used-natural, concrete recycling and ceramic recycling - and two types of reinforcing fibers: polypropylene and polyolefin. In this way, various tests of physical-mechanical characterization and a statistical analysis of the results were carried out. It has been shown that the mortars made from aggregate recycled concrete and reinforced with polypropylene fiber are the ones with the best properties for application in the construction sector, although without improving the properties of traditional mortars made from natural aggregate and without fibers.
\end{abstract}

Keywords: recycled aggregates; masonry mortars; polypropylene fiber; polyolefin fiber; waste management

\section{Introduction}

Construction and Demolition Waste (CDW) includes all inert materials resulting from the execution or demolition of building and civil engineering works [1]. The nature of this type of waste differs according to its source and collection process [2]. Source separation is essential for the effective initiation of a recycling and re-use process for these wastes [3], which in turn enables them to be reintroduced as raw materials into the manufacturing process using circular economy criteria [4].

Sand is the second most consumed raw material in the world and its scarcity in some countries is expected to have an impact on the development of the construction sector $[5,6]$. For this reason, it is necessary to reconcile the industrial growth of nations with the preservation of the environment [7], in such a way that an effective recycling route for CDWs is their crushing, grinding and separation to be used as aggregates [8]. At present, the most direct application of recycled aggregates is the execution of roads [9], prefabricated for building and civil works [10], and as a partial replacement for natural aggregate in the production of mortars and concrete [11]. However, several authors have investigated the properties of these raw materials and have made it possible to extend the field of application of these aggregates for the production of new construction materials $[12,13]$.

In this work, two types of recycled aggregates were used for the manufacture of mortars compared to natural aggregates. On the one hand, recycled concrete aggregates were used, so called because they have more than $90 \%$ crushed concrete and natural stone without mortar [14]. Additionally, on the other hand, recycled ceramic aggregates with a percentage of ceramic material not less than $70 \%$ are used [15]. 
In this way, the most relevant properties of this type of aggregates can be exposed. With regard to aggregate recycling of concrete, some researchers have found that for substitution rates higher than $25 \%$ of aggregate in the manufacture of mortars there is a decrease in the mechanical and physical properties of mortars [16]. This decrease in mortars made from $100 \%$ recycled concrete is translated into higher water absorption [17], higher sulfur content [18], lower density and compressive strength [19], less workability of the mixture requiring the use of plasticizers [20] and more retraction during setting [21]. Recycled aggregates from ceramic waste, on the other hand, have lower mechanical resistance than recycled concrete aggregates [22], which has a negative impact on the performance of masonry mortars made from this type of sand. Among the most important characteristics of mortars made with ceramic recycled aggregate are their excessive porosity and demand for kneading water [23], their high shrinkage values and their high fine content generated during their manufacture [24], their lightness [25] and its reduced durability in salt crystallization cycles [26].

On the other hand, and with the aim of improving the technical performance of mortars made from recycled aggregate, the incorporation of reinforcing fibers in this type of conglomerate materials has been studied during recent decades by several researchers [27]. In a first classification, reinforcing fibers can be differentiated into synthetic fibers, including, among others, glass fibers, basalt fibers or carbon fibers, and natural fibers such as coconut fibers, hemp fibers or wood fibers. Two synthetic fibers were used in this work: polypropylene and polyolefin. Polypropylene fiber has been used by some researchers to reduce shrinkage by drying, to reduce the possible formation of cracks and to improve mechanical behavior by reducing the fragility of the material [28,29]. Among the most recent studies carried out on mortars made from recycled aggregate, the use of this type of fiber to maintain the dimensional stability of mortars during setting is noteworthy [30], and also those that use this type of reinforcement to reduce cracking in lightweight prefabricated panels that are to be subjected to flexotraction stresses [31]. On the other hand, polyolefin fibers have traditionally been used for the production of concrete reinforced with fibers, obtaining good results in reducing cracking and increasing the ductility of the material [32,33]. Among its most recent applications in the production of recycled mortars, the one made by J.C. Slebi-Acevedo et al. stands out [34], where, using polyolefin fibers, they have managed to improve mechanical resistance and reduce cracking of mortars made from asphalt residues. These are therefore two reinforcing materials that have proven their applicability in different construction materials and whose study can help to improve the mechanical performance of mortars made from recycled aggregate. Finally, it is worth mentioning the recent research carried out by Cascardi, A. et al. [35], which highlighted the importance of using connectors to improve the bearing capacity of multi-sheet masonry walls, using different types of materials and connector geometries, proposing an empirical model of great relevance for the construction sector.

In the light of the previous studies described, the aim of this research was to analyze the physical and mechanical properties of mortars made from recycled aggregate and reinforced with synthetic fibers. To this end, different series of mortars were developed with recycled ceramic and concrete aggregates, to evaluate their performance and determine the effect that the incorporation of polypropylene or polyolefin fibers into hardened mortar samples causes. All these results were compared with samples made from natural aggregate, with the aim of establishing a reference series that allows a statistical discussion and conclusions to be drawn based on the properties achieved by traditional mortars.

\section{Materials and Methodology}

This section describes the raw materials used in the production of masonry mortars, the dosages used and the experimental program carried out. 


\subsection{Materials}

\subsubsection{Cement}

The conglomerating material used for this investigation was CEM IV / B (P-V) $32.5 \mathrm{~N}$ cement, the description of which is given in the Cement Reprocessing Instruction RC-08 [36]. According to the data sheet of the manufacturer Cemex S.A. (Toledo, Spain), it is a cement of type puzolanic, with addition of siliceous flywheel ash (between 36 and $55 \%$ by mass), low content in Clinker (between 45 and $64 \%$ by mass) and low heat of hydration, with an average strength class of $32.5 \mathrm{~N}$ and ordinary initial resistance. In addition, it can contain setting regulator compounds (between 0 and $5 \%$ by mass).

On the other hand, Table 1 shows the most important physical and chemical properties for this type of cement:

Table 1. Most relevant physical and chemical characteristics of CEM cement IV / B (P-V) $32.5 \mathrm{~N}$.

\begin{tabular}{|c|c|c|c|c|c|}
\hline $\begin{array}{l}\text { Expansion Le } \\
\text { Chatelier }\end{array}$ & $\begin{array}{c}\text { Initial Compressive } \\
\text { Strength (MPa) }\end{array}$ & $\begin{array}{c}\text { Compressive Strength at } \\
28 \text { Days (MPa) }\end{array}$ & Sulphate $(\%)$ & Chloride (\%) & $\begin{array}{l}\text { True Density } \\
\quad\left(\mathrm{g} / \mathrm{cm}^{3}\right)\end{array}$ \\
\hline $0.1 \mathrm{~mm}$ & $\geq 16.0$ & $\geq 32.5 \mathrm{y} \leq 52.5$ & $\leq 3.5$ & $\leq 0.1$ & 3.01 \\
\hline
\end{tabular}

${ }^{1}$ The true density of cement was determined according to UNE 80,103 [37].

In this way, it can be observed that it is a cement that is optimal for use in the production of masonry mortars, since it meets the resistance and properties desired for the application of this type of material on site.

\subsubsection{Aggregates}

Three types of aggregates were used in this research: natural sand (NA), recycled sand from concrete waste (RA-Con) and recycled sand from ceramic waste (RA-Cer).

First, the granulometry of the three types of aggregates used was determined. To determine this grain size, metal sieves with standard maya lights between 4000 and $0.063 \mathrm{~mm}$, in accordance with UNE-EN 933-2 [38] were used. The results are shown in Figure 1.

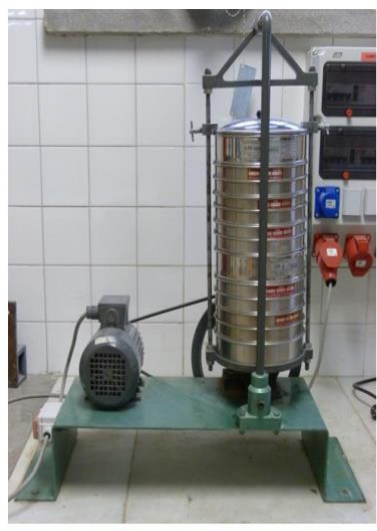

(a)

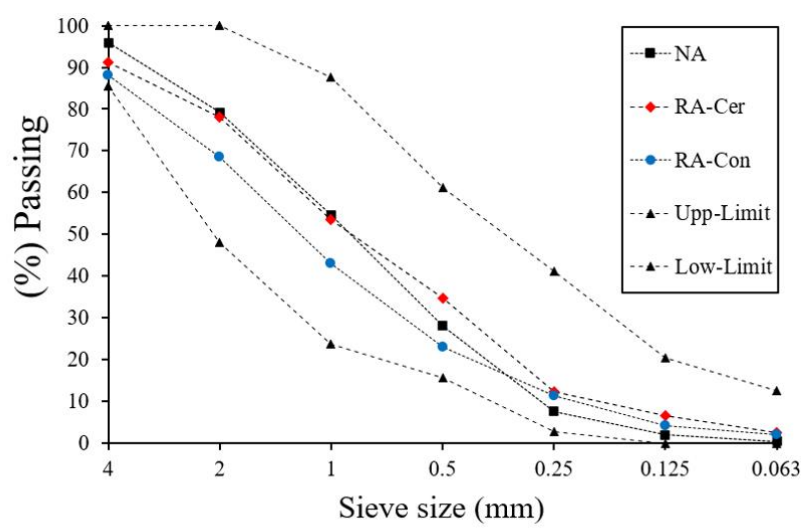

(b)

Figure 1. (a) Mechanical sieve for swinging (Sieves used 4.000-2.000-1.000-0.500-0.250-0.125-0.063Background); (b) recycled aggregate size distribution curve compared to the limits of NBE-FL 90 [39].

As can be seen in Figure 1, a continuous distribution was obtained for the three types of aggregates used, which has a positive effect on the production of masonry mortars giving them good workability, less porosity and greater final resistance [40].

On the other hand, Table 2 shows the results derived from the physical characterization of the aggregates used in this work according to the recommendations of standard UNEEN 13139:2002 [41]. For this type of test, aggregate fractions between 4000 and $0.063 \mathrm{~mm}$ were used, with the exception of the determination of the fine content and the fineness 
module where samples with particle size ranges between the $4000 \mathrm{~mm}$ sieve and the bottom were used.

Table 2. Physical characterization of the aggregates used.

\begin{tabular}{ccccc}
\hline Test & Standard & NA & RA-Con & RA-Cer \\
\hline Fine Content (\%) & UNE-EN 933-1 [42] & 1.86 & 3.34 & 4.12 \\
\hline Particle Form & UNE-EN 13139 [41] & Not Relevant & Not Relevant & Not Relevant \\
\hline $\begin{array}{c}\text { Fineness } \\
\text { Modulus (\%) }\end{array}$ & UNE-EN 13139 [41] & 4.32 & 4.08 & 4.32 \\
\hline Friability & UNE-EN 146404 [43] & 20.87 & 23.13 & 26.12 \\
\hline $\begin{array}{c}\text { Bulk Density } \\
\left(\mathrm{kg} / \mathrm{m}^{3}\right)\end{array}$ & UNE-EN 1097-3 [44] & 1563 & 1341 & 1276 \\
\hline $\begin{array}{c}\text { Dry Density } \\
\left(\mathrm{kg} / \mathrm{m}^{3}\right)\end{array}$ & UNE-EN 1097-6 [45] & 2506 & 2342 & 2189 \\
\hline $\begin{array}{c}\text { Water } \\
\text { Absorption }(\%)\end{array}$ & UNE-EN 1097-6 [45] & 0.93 & 6.12 & 8.16
\end{tabular}

Table 2 shows how the fine content of recycled aggregates from construction and demolition waste is much higher than that of natural aggregates. This higher fine content has a negative impact on the mechanical properties of masonry mortars made with this type of aggregate. It should also be noted that the density of the natural aggregate is higher than that of the recycled aggregates used in this study, with the aggregate ceramic recycling being the one that presented lower values for this property. The percentage of water absorption of recycled aggregates is much higher than that of natural aggregates, resulting in a higher demand for kneading water for the manufacture of construction mortars with this type of recycled aggregate [46].

Finally, the elemental chemical composition of the recycled aggregates was analyzed using the X-ray fluorescence technique. The results of this qualitative and quantitative analysis are shown in Table 3.

Table 3. Percentage values of the different compounds found in the X-ray fluorescence analysis.

\begin{tabular}{ccccccccccccc}
\hline Sample & $\mathrm{Al}_{\mathbf{2}} \mathbf{O}_{\mathbf{3}}$ & $\mathbf{C a O}$ & $\mathrm{Fe}_{2} \mathbf{O}_{\mathbf{3}}$ & $\mathbf{K}_{\mathbf{2}} \mathbf{O}$ & $\mathbf{M g O}$ & $\mathrm{SiO}_{2}$ & $\mathbf{M n O}$ & $\mathrm{TiO}_{2}$ & $\mathbf{S O}_{3}$ & $\mathbf{P}_{2} \mathbf{O}_{5}$ & $\mathbf{N a O}_{2}$ & $\mathbf{P e ́ r d i d a}$ \\
\hline RA-Con & 5.91 & 12.46 & 1.37 & 2.25 & 0.52 & 63.7 & 0.019 & 0.21 & - & 0.05 & 0.50 & 13.00 \\
RA-Cer & 12.89 & 16.54 & 3.31 & 1.96 & 1.82 & 43.1 & - & 0.22 & 3.11 & 0.14 & 0.68 & 16.23 \\
\hline
\end{tabular}

Thus, the percentage values collected in Table 3 for each of the chemical compounds found in the aggregates used show how the oxides of aluminum, calcium and silicon are the majority in the samples analyzed. The high percentage in $\mathrm{Al}_{2} \mathrm{O}_{3}$ in sands from ceramic waste due to its clay content can also be seen [47]. There are in turn high percentages of $\mathrm{CaO}$ in both types of aggregates which are due to the impurities of plaster or plaster contained in these materials since their grinding and grinding process [48].

\subsubsection{Fibers}

In this work, synthetic fibers of plastic origin were used as reinforcement material in mortars made with recycled aggregate, with the aim of increasing its durability, improving its mechanical resistance and reducing its retraction [49]. The fibers were supplied by SIKA (Madrid, Spain). It is a type of fiber resistant to ultraviolet rays, inert to alkali cement and other acids in general and resistant to fungi and bacteria.

Tables 4 and 5 show the results of the most relevant physical properties for the two types of fibers used in this study: polypropylene and polyolefin, respectively, obtained from the information provided by the supplier [50]. 
Table 4. Properties of Polypropylene Fibers.

\begin{tabular}{cccccc}
\hline $\begin{array}{c}\text { Density } \\
(\mathrm{Kg} / \mathrm{L})\end{array}$ & $\begin{array}{c}\text { Elongation } \\
\text { at Break (\%) }\end{array}$ & Length $(\mathbf{m m})$ & $\begin{array}{c}\text { Toughness } \\
(\mathbf{M P a})\end{array}$ & $\begin{array}{c}\text { Melting } \\
\text { Point }\left({ }^{\circ} \mathbf{C}\right)\end{array}$ & $\begin{array}{c}\text { Diameter } \\
(\mu \mathrm{m})\end{array}$ \\
\hline 0.910 & $80-140$ & 12 & $280-310$ & $163-170$ & 31 \\
\hline
\end{tabular}

Table 5. Properties of Polyolefin Fibers.

\begin{tabular}{cccccc}
\hline $\begin{array}{c}\text { Density } \\
(\mathbf{K g} / \mathrm{L})\end{array}$ & $\begin{array}{c}\text { Tensile Strength } \\
(\mathbf{M P a})\end{array}$ & $\begin{array}{c}\text { Length } \\
(\mathbf{m m})\end{array}$ & $\begin{array}{c}\text { Elasticity } \\
\text { Module }(\mathbf{M P a})\end{array}$ & $\begin{array}{c}\text { Melting } \\
\text { Point }\left({ }^{\circ} \mathbf{C}\right)\end{array}$ & $\begin{array}{c}\text { Diameter } \\
(\mathbf{m m})\end{array}$ \\
\hline 0.901 & 450 & 12 & 7500 & 164 & 0.84 \\
\hline
\end{tabular}

As shown in Tables 4 and 5, these are fibers with good tensile strength and similar densities. A length of $12 \mathrm{~mm}$ was chosen as optimal for mortar production, as an excessive length of the fibers may hinder kneading and favor the agglomeration of fibers that decrease the final mechanical properties of the hardened mortar [51].

\subsubsection{Water and Additive}

In this work, the additive MasterRheobuild 2100 was used as a water reducer and hardening accelerator in mortars made with recycled aggregate. It is a liquid product based on synthetic polymers of melamine free of chlorides, which is added in an amount of $1 \%$ on the mass of cement. It is a compound that has basic $\mathrm{pH}(8.5)$, a density of $1.12 \mathrm{~g} / \mathrm{cm}^{3}$, is colorless and does not occlude air. This additive has been used successfully in other works for improving the workability of mortars with the incorporation of Construction and Demolition Waste [52].

On the other hand, during the kneading process of masonry mortars, drinking water was used from the Isabel II Canal in the Community of Madrid, Spain. It is soft water $\left(\mathrm{mg} \mathrm{CaCO}_{3} / \mathrm{L}\right)$ with a $\mathrm{pH}$ of approximately 7.9 , meeting the minimum $\mathrm{pH} 5$ requirement in EHE-08 [53]. This water contains no contaminants that can alter the ultimate properties of mortars made from it.

\subsection{Experimental Programme}

\subsubsection{Dosages Used}

For this work, a cement/aggregate ratio was used for each type of sand used in the manufacture of mortars. In addition, the recommendations of standard UNE-EN 196-1 were followed during the preparation of the various mixes [38], following in all cases the same techniques and methods. For its part, the notation used to name the different dosages follows the following nomenclature:

\section{Aggregate-Ratio-Fiber}

where Aggregate refers to the type of aggregate that can be: Natural (NA), Recycling from Concrete Waste (RA-Con) or Recycling from Ceramic Waste (RA-Cer), Ratio refers to the cement/aggregate weight ratio of 1:3 for this research, and Fiber refers to the type of reinforcing fiber used: polypropylene (FPP) or polyolefin (FPA).

The different proportions of each raw material used in each dosage are shown in Table 6. It should be noted that for a correct kneading, the fibers were separated manually and poured continuously during the kneading process in order to avoid cross-linking between them [54].

In addition, it should be noted that the mixing water content used in the various mixes listed in Table 6 was experimentally fixed. For this purpose, the criteria of standard UNE-EN 1015-2: 2007 were followed to obtain a plastic and workable consistency according to the shaking table method [55], corresponding to the diameter of the mortar paste of $175 \pm 10 \mathrm{~mm}$. The results of the consistency obtained for each dose are shown in Figure 2. 
Table 6. Dosages used for the preparation of mortars.

\begin{tabular}{cccccc}
\hline Type & Cement $(\mathbf{g})$ & Aggregate $(\mathrm{g})$ & Water $(\mathrm{g})$ & Fiber $_{(\mathrm{g})}{ }^{*}$ & Additive $(\mathrm{g}) * *$ \\
NA-1:3 & 450.0 & 1350.0 & 261.0 & - & - \\
RA-Con-1:3 & 450.0 & 1350.0 & 301.5 & - & 4.5 \\
RA-Cer-1:3 & 450.0 & 1350.0 & 337.5 & 2.5 & 4.5 \\
RA-Con-1:3-FPP & 450.0 & 1350.0 & 301.5 & 2.5 & 4.5 \\
RA-Cer-1:3-FPP & 450.0 & 1350.0 & 337.5 & 5 & 4.5 \\
RA-Con-1:3-FPA & 450.0 & 1350.0 & 301.5 & 5 & 4.5 \\
RA-Cer-1:3-FPA & 450.0 & 1350.0 & 337.5 & 4.5 \\
\hline
\end{tabular}

* In order to determine the quantity of fibers added in each dosage, their density was taken into account. ${ }^{* *}$ The additive content is $1 \%$ by weight of the cement mass.

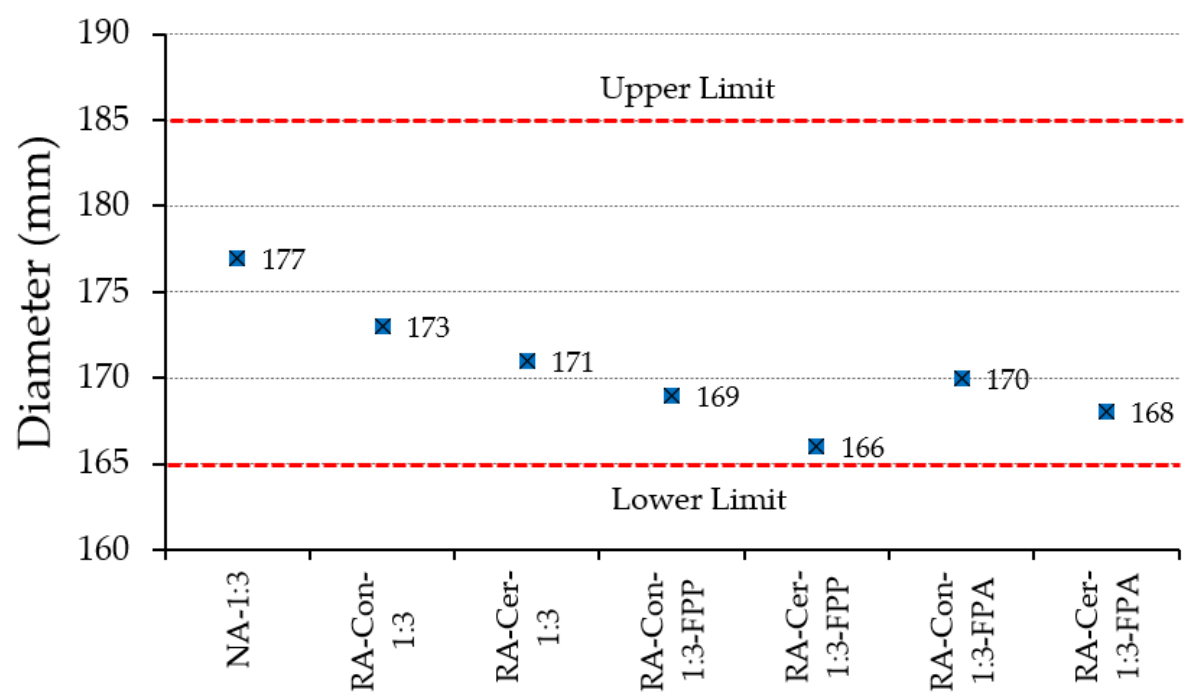

Figure 2. Consistency test results according to standard UNE-EN 1015-2: 2007 [54].

As can be seen in Figure 2, the consistency values for mortars made from recycled aggregate are lower than those obtained for the biker made from natural aggregate. In addition, the incorporation of fibers during kneading decreases the workability of mortars in the fresh state [56]. However, in all cases the values obtained for consistency are within the limits set by the regulations to be considered plastic. Finally, it should be noted that the cost per $\mathrm{m}^{3}$ of mortar would be approximately EUR 72 in the case of incorporating FPP and EUR 75 in the case of incorporating FPA.

\subsubsection{Methodology}

The following physical and mechanical characterization tests included in Table 7 were carried out in this research. The reference standards used and the dimensions of the test pieces are included.

Table 7. Physical and mechanical characterization tests performed.

\begin{tabular}{ccc}
\hline Property & Standard & Samples \\
\hline Flexural strength & & \\
Compressive strength & UNE-EN 1015-11:2000/A1:2007 [57] & RILEM $40 \times 40 \times 160 \mathrm{~mm}^{3}$ \\
Shore hardness D & UNE-EN 1015-18 [58] & \\
Water Absorption by Capillarity & UNE-EN 1015-10:2000/A1:2007 [59] & \\
Bulk Density & UNE-EN 1015-12:2016 [60] & $\begin{array}{c}\text { Ceramic scraper with a 2 cm-thick layer of mortar } \\
\text { Adherence }\end{array}$ \\
Retraction & UNE 80-112-89 [61] & Prismatic 25 $\times 25 \times 287 \mathrm{~mm}^{3}$ \\
\hline
\end{tabular}


In addition, in order to better understand the composition of hardened mortar matrices, Scanning Electron Microscopy (SEM) tests were carried out on some of the series made with recycled aggregate, with and without fibers. A Nova Nano SEM230 (FEG-SEM) microscope was used for this purpose.

On the other hand, an analysis of variance (ANOVA) was carried out to evaluate the differences between the different properties of the mortars produced with recycled aggregate in this investigation. The factors and levels used for this analysis are listed in Table 8. In addition, to determine the technical competitiveness of recycled mortars with synthetic fiber incorporation, 95\% confidence intervals were built for the difference in means between these mortars and bikers made from natural aggregate.

Table 8. Factors and levels used for the analysis of variance (ANOVA).

\begin{tabular}{ccc}
\hline Factors & Levels & Nomenclature \\
\hline Aggregate type & Concrete/Ceramic & RA-Con/RA-Cer \\
Fiber type & Polypropylene/Polyolefin & FPP/FPA \\
\hline
\end{tabular}

\section{Results and Discussion}

\subsection{Mechanical Resistance to Flexural and Compression}

Figure 3 shows the results of the flexural and compression strength tests carried out on test pieces of $4 \times 4 \times 16 \mathrm{~cm}^{3}$ of each of the mixes. The test pieces were tested at the age of 28 days after being cured in a wet chamber under conditions of $95 \%$ relative humidity and ambient temperature of $23^{\circ} \mathrm{C}$.

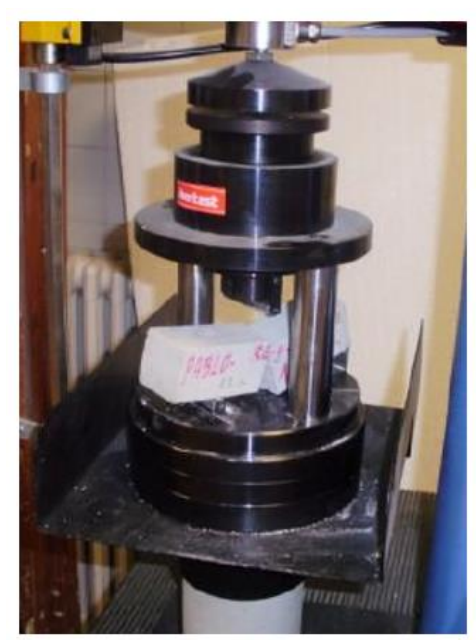

(a)

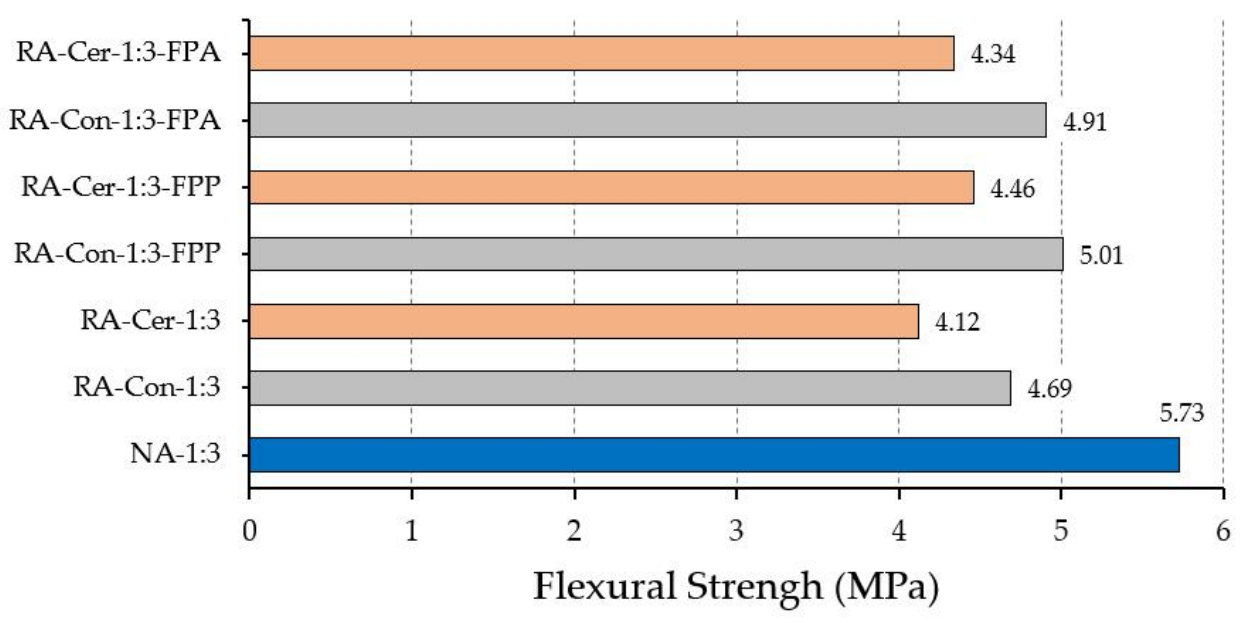

(b)

Figure 3. (a) Flexural strength test; (b) results of the flexural strength test.

As can be seen in Figure 3, the bending resistance of traditional mortars made from natural aggregate is higher than that achieved by mortars made from recycled aggregate. However, it can be seen that mortars made from recycled aggregate of concrete have higher bending resistance values than mortars made from ceramic recycled aggregate. There are also differences between the type of synthetic reinforcement fiber added. Table 9 shows the ANOVA analysis for this property. 
Table 9. Analysis of the Variance for the values of Flexural Resistance (MPa).

\begin{tabular}{cccccc}
\hline Source & Sum of Squares & df & Mean Square & F-Ratio * & $p$-Value \\
\hline A: RA-Type & 1.0860100 & 1 & 1.0860100 & 157.12 & 0.0000 \\
B: Fibers-Type & 0.1344080 & 1 & 0.1344080 & 19.45 & 0.0017 \\
Residual & 0.0622083 & 9 & 0.00691204 & & \\
Total (Corrected) & 1.2826200 & 11 & & & \\
* The $p$-values have been calculated at $95 \%$ confidence. & & &
\end{tabular}

As can be seen in Table 9, the two factors included in the study have a $p$-value lower than the level of significance $(\alpha=0.05)$ and are therefore considered statistically significant.

Below, in Table 10, the results for the multi-range test for this property are presented.

Table 10. Multiple range tests for Flexural Strength (MPa).

\begin{tabular}{ccccc}
\hline Factors & Count & LS Mean & LS Sigma & Homogeneous Group \\
\hline RA-Type & & & & \\
Cer & 6 & 4.39167 & 0.0339412 & $\mathrm{X}$ \\
Con & 6 & 4.99333 & 0.0339412 & \\
Fiber-Type & & & & $\mathrm{X}$ \\
FPA & 6 & 4.58667 & 0.0339412 & $\mathrm{X}$ \\
FPP & 6 & 4.79833 & 0.0339412 & \\
\hline
\end{tabular}

Thus, in Table 10, after the analysis of the multirange test, it can be observed that there are significant differences at all levels for each of the factors analyzed. In such a way that the mortars reinforced with fibers present better resistance to bending, the fiber of polypropylene is the better option for reinforcing rather than the fiber of polyolefin. In addition, it can be concluded by saying the RA-Con-1:3-FPP mixes were those that presented bending resistance closer to those achieved by traditional mortars.

Figure 4 shows the results obtained after the compression strength test for the various mix.

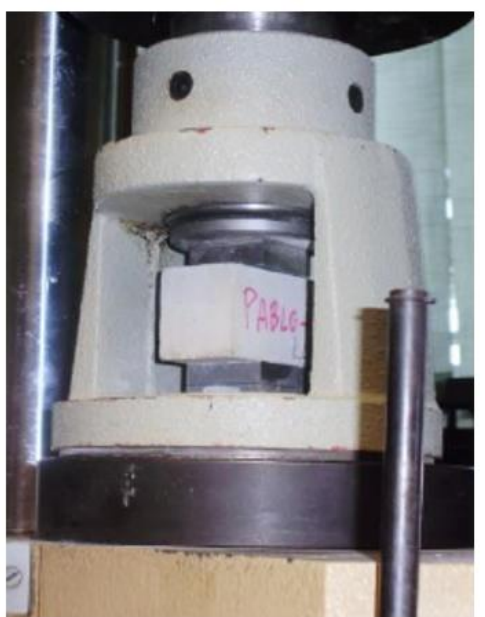

(a)

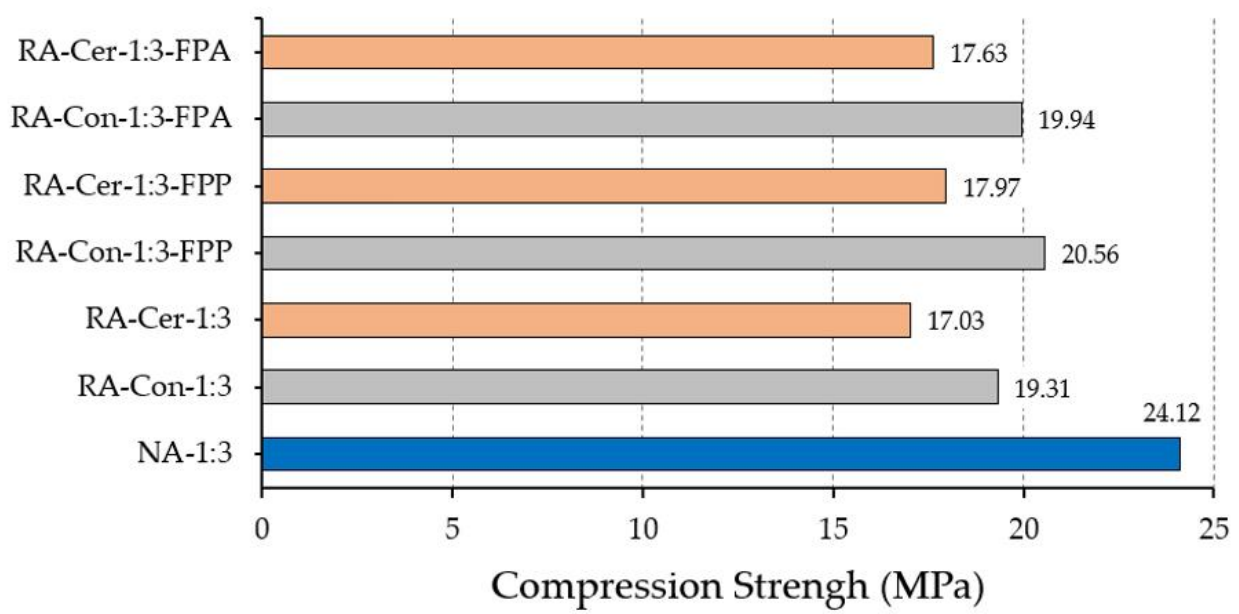

(b)

Figure 4. (a) Compressive strength test; (b) compressive strength test results.

It can be seen in Figure 4 as the mortars made with natural aggregate were the ones that showed the greatest resistance in this trial. In addition, it can be seen how the mortars made with recycled aggregate of concrete that possesses a greater density than the recycled ceramic aggregate, presented superior mechanical resistances. For this property, the addition of synthetic fibers has meant an increase in strength. Table 11 presents the 
ANOVA analysis for this property, where it can be seen that all the factors included in the study are significant by presenting a $p$-value lower than $\alpha=0.05$.

Table 11. Analysis of the Variance for the values of Compression Resistance (MPa).

\begin{tabular}{cccccc}
\hline Source & Sum of Squares & Df & Mean Square & F-Ratio * & $p$-Value \\
\hline A: RA-Type & 19.53300 & 1 & 19.533000 & 274.74 & 0.0000 \\
B: Fibers-Type & 0.935208 & 1 & 0.9352080 & 13.15 & 0.0055 \\
Residual & 0.639875 & 9 & 0.0710972 & & \\
Total (Corrected) & 21.10810 & 11 & & & \\
* The $p$-values have been calculated at 95\% confidence. & &
\end{tabular}

On the other hand, Table 12 shows the test of multiple ranges.

Table 12. Multiple range tests for Compression Strength (MPa).

\begin{tabular}{ccccc}
\hline Factors & Count & LS Mean & LS Sigma & Homogeneous Group \\
\hline RA-Type & & & & \\
Cer & 12 & 17.6733 & 0.108856 & $\mathrm{X}$ \\
Con & 12 & 20.225 & 0.108856 & \\
Fiber-Type & & & & $\mathrm{X}$ \\
FPA & 12 & 18.6700 & 0.108856 & $\mathrm{X}$ \\
FPP & 12 & 19.2283 & 0.108856 & \\
\hline
\end{tabular}

As can be observed in the test of multiple ranges indicated in Table 12, the levels "aggregate of concrete" and the type of fiber "Polypropylene" have statistically higher values and therefore the mixes incorporating these levels have a higher compressive strength.

It has been shown that the addition of synthetic fibers in the mold matrix makes it possible to stop cracking in the face of bending forces and improves the internal cohesion of the conglomerate material [62]. In addition, the compression resistances obtained are indicative of the quality of mortars made from recycled aggregate and reinforced with fibers, since they provide information on the capacity of the materials tested when it comes to bearing loads without breaking up [63]. In this way, it has been possible to observe how the addition of synthetic fibers in the percentages indicated in the research improves the mechanical strength of the mortars; similar results have also been obtained by other researchers who used natural fibers during the mixing process to improve the mechanical properties in this type of material [64].

To better observe this cohesion between the recycled aggregate and the conglomerate, and between fiber and mortar matrix, Figure 5 shows microscopy images of the RA-Con and RA-Con-1:3-FPP-type mixes.

As can be seen in Figure 5a, there is a correct setting and hardening of the cementitious material that is reflected in the formation of Ettringite crystals in the mortar matrix made from recycled aggregate. On the other hand, Figure $5 b$ also corresponding to test piece RA-Con-1:3 shows the good cohesion in the interface between the recycled aggregate of concrete and the conglomerating material, this has an impact on better compressive strength and less segregation of aggregates [65].

Figure $5 c, d$ show the interface between the polypropylene fiber and the mortar matrix in the RA-Con-1:3-FPP test pieces, which achieved the best bending results. It can be seen that there is a homogeneous distribution of the fibers inside the mortar and that they are well adhered.

\subsection{Physical Properties and Other Tests}

Table 13 shows the results corresponding to the other physical properties analyzed: surface hardness, bulk density, adhesion and water absorption by capillarity. 


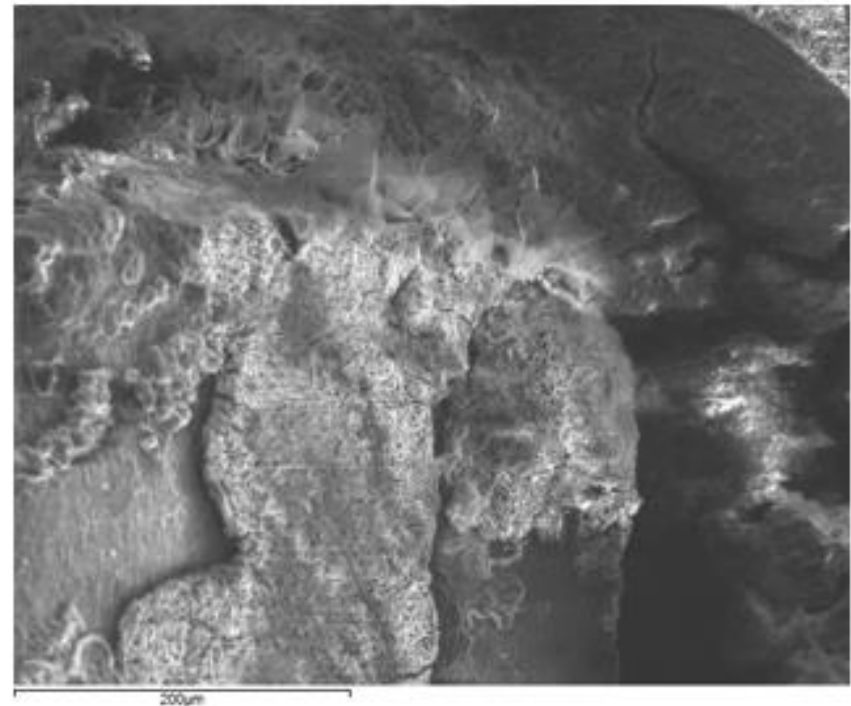

(a)

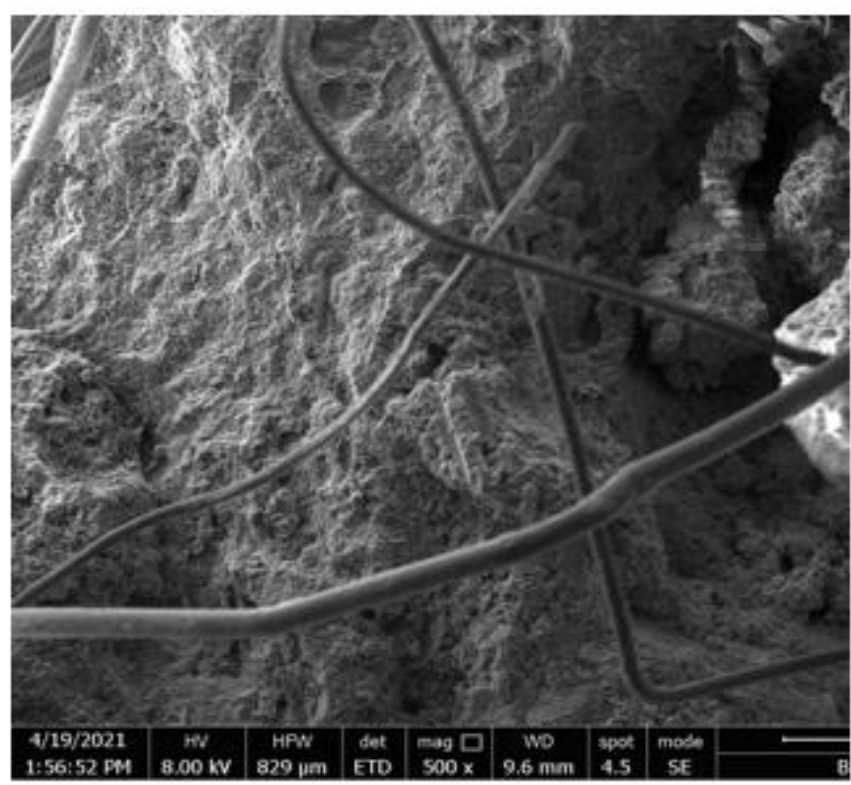

(c)

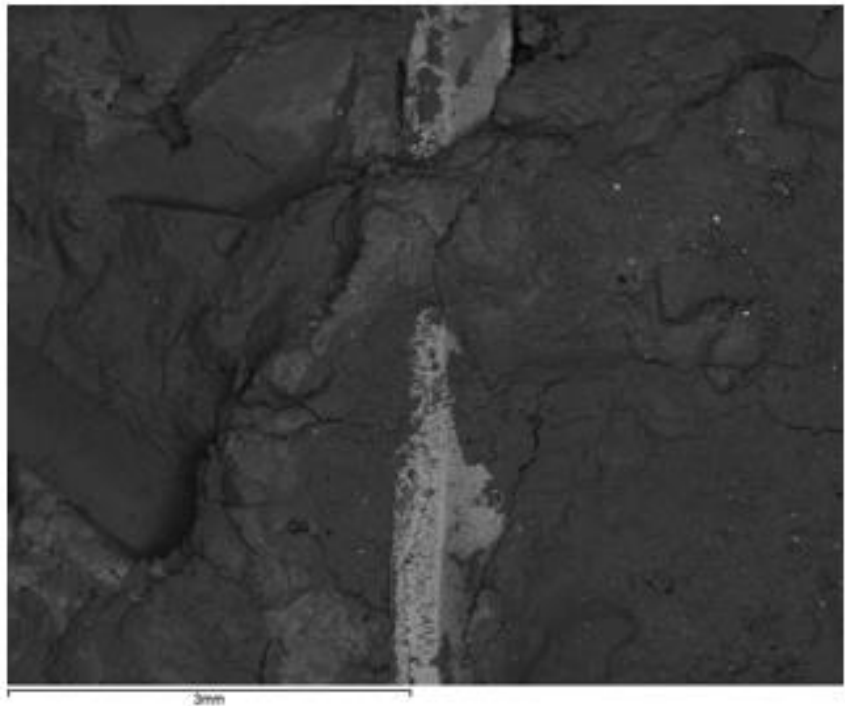

(b)

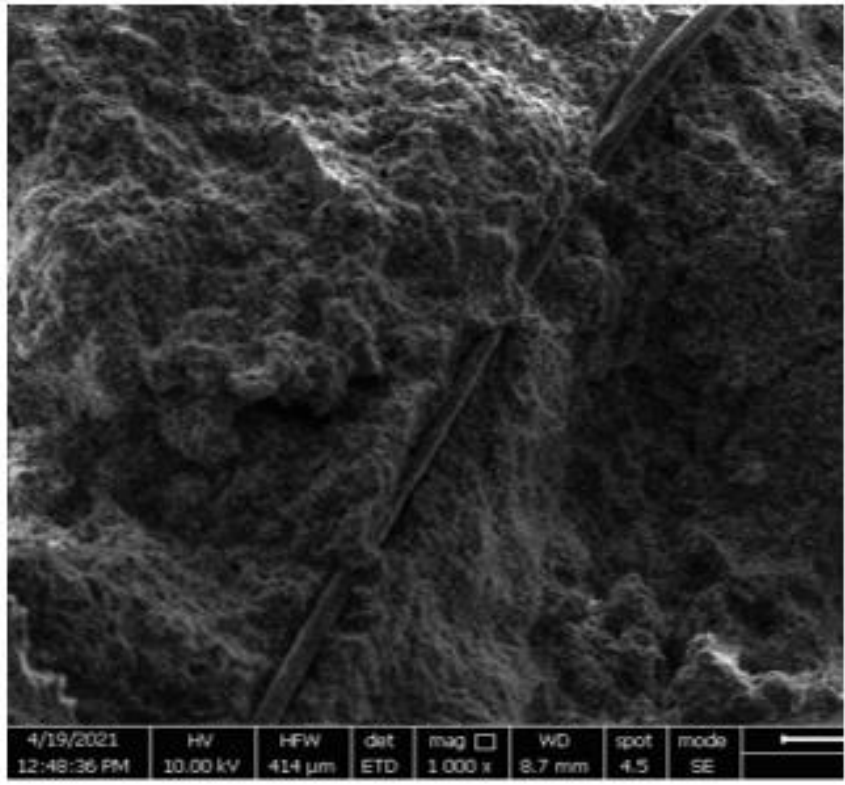

(d)

Figure 5. Scanning Electron Microscopy (SEM). (a,b) Sample RA-Con-1:3, (c,d) Sample RA-Con-1:3-FPP.

Table 13. Physical properties of processed mortars.

\begin{tabular}{ccccc}
\hline Type & $\begin{array}{c}\text { Hardness (Ud. } \\
\text { Shore D) }\end{array}$ & $\begin{array}{c}\text { Bulk Density } \\
\left(\mathbf{k g} / \mathbf{m}^{\mathbf{3}} \mathbf{)}\right.\end{array}$ & $\begin{array}{c}\text { Adherence } \\
\mathbf{( M P a )}\end{array}$ & $\begin{array}{c}\text { Absorption } \\
\left(\mathbf{k g} / \mathbf{m m}^{\mathbf{2}} \mathbf{m i n}^{\mathbf{0 . 5}} \mathbf{)}\right.\end{array}$ \\
\hline NA-1:3 & 81 & 2210 & 0.51 & 0.55 \\
RA-Con-1:3 & 73 & 1890 & 0.42 & 0.62 \\
RA-Cer-1:3 & 70 & 1780 & 0.43 & 0.68 \\
RA-Con-1:3-FPP & 74 & 1905 & 0.38 & 0.59 \\
RA-Cer-1:3-FPP & 70 & 1795 & 0.38 & 0.64 \\
RA-Con-1:3-FPA & 72 & 1940 & 0.36 & 0.6 \\
RA-Cer-1:3-FPA & 71 & 1810 & 0.37 & 0.62 \\
\hline
\end{tabular}


Table 13 shows that the mortars made with natural aggregate were the best results for the physical properties analyzed. With regard to the analysis of recycled mortars, firstly, the surface hardness Shore D was higher in the test pieces incorporating recycled aggregate of concrete, where it is also noted that the incorporation of fibers does not represent a significant improvement in this property. On the other hand, the bulk density was also higher in the test pieces incorporating the recycled aggregate of concrete and reinforced with fibers; this is due to the higher density of recycled concrete aggregates with respect to recycled ceramic aggregates as can be seen in Table 2.

In terms of adhesion, it has been shown that the incorporation of fibers does not improve the results for this property. The values reached for the adhesion tests of the mortar on a ceramic base reflect that the incorporation of recycled concrete aggregate in recycled mortars does not imply a variation for this property with respect to the incorporation of ceramic recycled aggregate, because in any case, it can be seen that the mortars made with ceramic recycled aggregate presented slightly higher values. Finally, the absorption of water by capillarity is much higher in mortars made with recycled aggregate compared to those made with traditional mortars, with the mortar made with ceramic recycled aggregate having the highest absorption coefficients.

In addition, a statistical analysis was carried out to verify whether or not there are statistically significant differences in all the physical properties studied. Table 14 shows the ANOVA test values for a significance level of $\alpha=0.05$ in all properties. Additionally, on the other hand, Table 15 shows the results obtained after performing the test of multiple ranges for the different factors and levels.

Table 14. Analysis of variance for physical properties.

\begin{tabular}{|c|c|c|c|c|c|c|}
\hline Property & Source & Sum of Squares & Df & Mean Square & F-Ratio * & $p$-Value \\
\hline \multirow[t]{4}{*}{ Surface hardness } & A: RA-Type & 15.1875 & 1 & 15.1875 & 15.44 & 0.0035 \\
\hline & B: Fibers-Type & 0.520833 & 1 & 0.520833 & 0.53 & 0.4854 \\
\hline & Residual & 8.85417 & 9 & 0.983796 & & \\
\hline & Total (Corrected) & 24.5625 & 11 & & & \\
\hline \multirow[t]{4}{*}{ Bulk density } & A: RA-Type & 42960.3 & 1 & 42960.3 & 2899.82 & 0.0000 \\
\hline & B: Fibers-Type & 1728.0 & 1 & 1728.0 & 116.64 & 0.0000 \\
\hline & Residual & 133.333 & 9 & 14.8148 & & \\
\hline & Total (Corrected) & 44821.7 & 11 & & & \\
\hline \multirow[t]{4}{*}{ Adherence } & A: RA-Type & 0.00140833 & 1 & 0.00140833 & 18.78 & 0.0019 \\
\hline & B: Fibers-Type & 0.00000833 & 1 & 0.00000833 & 0.11 & 0.7465 \\
\hline & Residual & 0.00067500 & 9 & 0.00007500 & & \\
\hline & Total (Corrected) & 0.00209167 & 11 & & & \\
\hline \multirow[t]{4}{*}{$\begin{array}{c}\text { Absorption by } \\
\text { Capillarity }\end{array}$} & A: RA-Type & 0.00403333 & 1 & 0.00403333 & 26.56 & 0.0006 \\
\hline & B: Fibers-Type & 0.00030000 & 1 & 0.00030000 & 1.98 & 0.1934 \\
\hline & Residual & 0.00136667 & 9 & 0.00015185 & & \\
\hline & Total (Corrected) & 0.00570000 & 11 & & & \\
\hline
\end{tabular}

* The $p$-values have been calculated at $95 \%$ confidence.

As can be seen from the analysis in Table 14, for the properties of adhesion, surface hardness and water absorption by capillarity, the only significant factor is the type of aggregate. This is not the case with density, where statistical significance for the fiber factor can be seen. In the same way, looking at Table 15, it can be appreciated how the mortars made with recycled aggregate of concrete have presented better results before the physical properties studied, the type of fiber added does not substantially improve the fiber content except in the case of bulk density.

In addition, Figure 6 shows the results obtained for the dimensional variation expressed as a percentage of shortening, which is caused by the retraction during the setting in the different mixes studied. 
Table 15. Multiple range test for physical properties.

\begin{tabular}{|c|c|c|c|c|c|}
\hline & Factors & Count & LS Mean & LS Sigma & Homogeneous Group \\
\hline \multirow[t]{6}{*}{ Surface hardness } & RA-Type & & & & \\
\hline & Cer & 6 & 70.50 & 0.404927 & $x$ \\
\hline & Con & 6 & 72.75 & 0.404927 & $X$ \\
\hline & Fiber-Type & & & & \\
\hline & FPA & 6 & 71.4167 & 0.404927 & $x$ \\
\hline & FPP & 6 & 71.8333 & 0.404927 & $x$ \\
\hline \multirow[t]{6}{*}{ Bulk density } & RA-Type & & & & \\
\hline & Cer & 6 & 1802.00 & 1.57135 & $x$ \\
\hline & Con & 6 & 1921.67 & 1.57135 & $x$ \\
\hline & Fiber-Type & & & & \\
\hline & FPP & 6 & 1849.83 & 1.57135 & $x$ \\
\hline & FPA & 6 & 1873.83 & 1.57135 & $X$ \\
\hline \multirow[t]{6}{*}{ Adherence } & RA-Type & & & & \\
\hline & Cer & 6 & 0.36500 & 0.00353553 & $x$ \\
\hline & Con & 6 & 0.38667 & 0.00353553 & $x$ \\
\hline & Fiber-Type & & & & \\
\hline & FPA & 6 & 0.37500 & 0.00353553 & $X$ \\
\hline & FPP & 6 & 0.37667 & 0.00353553 & $x$ \\
\hline \multirow{6}{*}{$\begin{array}{l}\text { Absorption by } \\
\text { Capillarity }\end{array}$} & RA-Type & & & & \\
\hline & Con & 6 & 0.59667 & 0.00503077 & $X$ \\
\hline & Cer & 6 & 0.63333 & 0.00503077 & $x$ \\
\hline & Fiber-Type & & & & \\
\hline & FPA & 6 & 0.61 & 0.00503077 & $x$ \\
\hline & FPP & 6 & 0.62 & 0.00503077 & $x$ \\
\hline
\end{tabular}

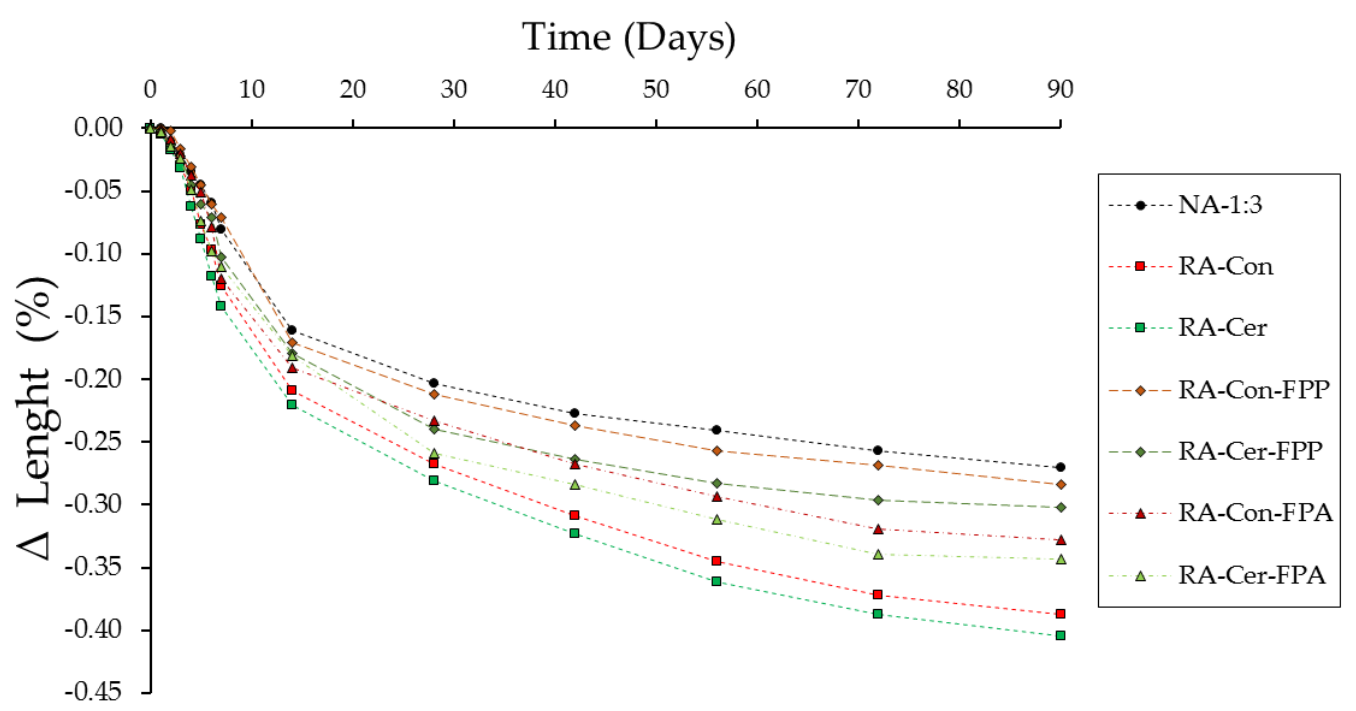

Figure 6. Evolution of the retraction during the setting. Variation of the percentage of shortening versus time in days.

As can be seen from the analysis in Figure 6, traditional mortars made from natural aggregate have greater dimensional stability and less shrinkage than mortars made from recycled aggregate. Within these recycled mortars, those made with ceramic recycled aggregate had higher shrinkage values than their counterparts made with recycled aggregate of concrete. Thus, it can be verified that, in accordance with other studies, the incorporation of this type of CDW in the manufacture of mortars increases the shrinkage in mortars [66].

However, these retraction values are reduced with the incorporation of fibers in the mortar matrix, with better results presented for the addition of polypropylene fiber rather than polyolefin fiber. In fact, the RA-Con-1:3-FPP dosage is the one that best approximates its behavior to the mortar made with natural aggregate. 


\subsection{Statistical Discussion. Confidence Intervals for Mean Difference}

Finally, confidence intervals were calculated for the difference in mean to $95 \%$ confidence in order to determine the technical competitiveness of the studies carried out for this research. These ranges were constructed to assess the differences between traditional mortars (NA-1:3) with respect to mortars made from recycled aggregate and polypropylene fiber (RA-Con-1:3-FPP), and to analyze the differences in means between the latter and the mortars made with recycled aggregate and without fibers (RA-Con-1:3). These dosages were chosen based on the analysis of the variance performed, since they were the best results for the different trials.

In addition, for the performance of this statistical analysis it was necessary to increase the sample size up to 30 specimens of each type of mortar analyzed to obtain reliable results.

The intervals obtained in this analysis are shown in Table 16, arranged according to each property evaluated.

Table 16. Confidence intervals for mean difference at 95\% confidence.

\begin{tabular}{ccccc}
\hline Property & Contrast & Range & Contrast & Range \\
\hline Flexural strength (MPa) & & {$[0.32992 ; 0.45608]$} & & {$[-0.72851 ;-0.54882]$} \\
Compressive strength (MPa) & NA $-1: 3(\mu x)$ & {$[3.42191 ; 4.37742]$} & RA - Con $-1: 3(\mu x)$ & {$[-1.21979 ;-0.71754]$} \\
Hardness (Ud. Shore D9) & vs. & {$[5.11745 ; 7.48255]$} & {$[-1.03257 ; 0.83257]$} \\
Density $\left(\mathrm{kg} / \mathrm{m}^{3}\right)$ & $\mathrm{RA}-\mathrm{Con}-1: 3-\mathrm{FPP}(\mu \mathrm{Y})$ & {$[292.737 ; 306.597]$} & $\mathrm{RA}-\mathrm{Von}-1: 3-\mathrm{FPP}(\mu Y)$ & {$[-22.5427 ;-13.3907]$} \\
Adherence $(\mathrm{MPa})$ & & {$[0.09294 ; 0.11639]$} & {$[0.00235 ; 0.02031]$} \\
Capillary Absorption & & $-0.04752 ;$ & & {$[-0.00164 ; 0.01631]$} \\
$\left(\mathrm{kg} / \mathrm{mm}^{2} \mathrm{~min}^{0.5}\right)$ & & & & \\
\hline
\end{tabular}

To analyze the confidence intervals calculated in Table 16, it should be noted that the difference in means has always been calculated as the minus of $\left(\mu_{x}-\mu_{y}\right)$ at $95 \%$ confidence. From the comparison between the mixes RA-Con-1:3 and RA-Con-1:3-FPP, a significant improvement in the performance of the mortars incorporating polypropylene fibers in terms of bending and compression resistance is observed, with the mixes able to achieve improvements of around 0.70 and $1.2 \mathrm{MPa}$, respectively. In the rest of the tested properties, a behavior similar to recycled mortars that do not incorporate fibers is observed.

On the other hand, the difference in calculated means between mortars made from natural aggregate and recycled mortars that incorporate polypropylene fibers shows a better performance in traditional mortars in all the tested properties. However, in the resistance to bending and compression, the difference in performance is reduced between both types of mortar, justifying the incorporation of fibers in recycled mortars to increase their competitiveness as masonry mortars.

\section{Conclusions}

In this work, the mechanical properties of cement mortars reinforced with synthetic fibers and made with recycled aggregate were analyzed. The technical feasibility of these materials for use in the construction sector as masonry mortars was verified. In this way, this study has contributed with the provision of technical information of interest to construction professionals who wish to use more sustainable and environmentally friendly materials, thus contributing to achieving the objective of promoting cleaner production through the efficient use of natural resources, as set out in the European 2030 Agenda.

As for the mechanical properties, the tests carried out show that the recycled aggregate of concrete allows obtaining mortars with better results in terms of resistance to bending and compression, in comparison with the mortars made with ceramic recycled aggregate. In addition, polypropylene fiber is presented as a better synthetic reinforcement material than polyolefin fiber to improve the mechanical properties of recycled mortars. However, in all cases analyzed, traditional mortars have performed better than recycled mortars. On the other hand, the correct setting of the mortars made with recycled aggregate was demonstrated, as well as its good internal cohesion and good adhesion between the fibers and the mortar matrix thanks to the analysis by electron microscopy of low flow. 
With regard to the other physical properties analyzed—surface hardness, adhesion, bulk density, capillary water absorption and shrinkage-traditional mortars with natural aggregate are still the ones with the best results. As for hardness, the incorporation of fibers does not imply a modification of this property and better results were presented for mortars with aggregate recycled concrete. Regarding the adhesion and absorption of water by capillarity, the mortars made with ceramic recycled aggregate presented higher values for this property and were also lighter than the mortars made with recycled aggregate of concrete. Finally, the positive effect of the incorporation of synthetic fibers in the mortar matrix in reducing shrinkage during setting was verified. In this sense, mortars with recycled concrete aggregate have a less retraction than mortars with ceramic recycled aggregate, and this shrinkage for both types of recycled mortars is reduced more by the incorporation of polypropylene fibers than by the incorporation of polyolefin fibers.

Author Contributions: Conceptualization, D.F. and C.M.; methodology, D.F.; software, P.S.; validation, D.F., P.S. and A.M.; formal analysis, C.M. and G.V.; investigation, D.F.; resources, G.V. and C.M.; data curation, D.F.; writing —original draft preparation, D.F. and P.S.; writing-review and editing, A.M.; visualization, A.M.; supervision, C.M.; project administration, C.M.; funding acquisition, G.V. All authors have read and agreed to the published version of the manuscript.

Funding: This research received no external funding.

Institutional Review Board Statement: Not applicable.

Informed Consent Statement: Not applicable.

Acknowledgments: The authors would like to thank the Materials Laboratory of the E.T.S. Edificación of Madrid the technical support provided during the tests. In addition, they also want to thank the University of Guayaquil for the availability to carry out interuniversity collaborations with research staff from the Polytechnic University of Madrid.

Conflicts of Interest: The authors declare no conflict of interest.

\section{References}

1. Fueyo, L. Mejoras Tecnológicas en el Reciclado de Residuos de Construcción y Demolición (RCD). Ph.D. Thesis, Universidad Politécnica de Madrid, Madrid, Spain, 2012.

2. Liu, H.; Long, H.; Li, X. Identification of critical factors in construction and demolition waste recycling by the grey-dematel approach: A Chinese perspective. Environ. Sci. Pollut. Res. 2020, 27, 8507-8525. [CrossRef] [PubMed]

3. Saez, P.V.; Merino, M.D.R.; González, A.S.-A.; Porras-Amores, C. Best practice measures assessment for construction and demolition waste management in building constructions. Resour. Conserv. Recycl. 2013, 75, 52-62. [CrossRef]

4. Al-Hamrani, A.; Kucukvar, M.; Alnahhal, W.; Mahdi, E.; Onat, N.C. Green Concrete for a Circular Economy: A Review on Sustainability, Durability, and Structural Properties. Materials 2021, 14, 351. [CrossRef] [PubMed]

5. Bao, Z.; Lu, W.; Chi, B.; Yuan, H.; Hao, J. Procurement innovation for a circular economy of construction and demolition waste: Lessons learnt from Suzhou, China. Waste Manag. 2019, 99, 12-21. [CrossRef] [PubMed]

6. Jesus, S.; Pederneiras, C.M.; Farinha, C.B.; De Brito, J.; Veiga, R. Reduction of the Cement Content by Incorporation of Fine Recycled Aggregates from Construction and Demolition Waste in Rendering Mortars. Infrastructures 2021, 6, 11. [CrossRef]

7. Bao, Z.; Lu, W. Developing efficient circularity for construction and demolition waste management in fast emerging economies: Lessons learned from Shenzhen, China. Sci. Total Environ. 2020, 724, 138264. [CrossRef] [PubMed]

8. Tambovceva, T.; Urbane, V.; Ievins, J. Innovations in Construction Waste Management: Case of Latvia. Mark. Manag. Innov. 2020, 3, 234-248. [CrossRef]

9. Agrela, F.; Díaz-López, J.; Rosales, J.; Cuenca-Moyano, G.; Cano, H.; Cabrera, M. Environmental assessment, mechanical behavior and new leaching impact proposal of mixed recycled aggregates to be used in road construction. J. Clean. Prod. 2021, 280, 124362. [CrossRef]

10. Sánchez-Roldán, Z.; Martín-Morales, M.; Valverde-Espinosa, I.; Zamorano, M. Technical feasibility of using recycled aggregates to produce eco-friendly urban furniture. Constr. Build. Mater. 2020, 250, 118890. [CrossRef]

11. Ohemeng, E.A.; Ekolu, S.O. Comparative analysis on costs and benefits of producing natural and recycled concrete aggregates: A South African case study. Case Stud. Constr. Mater. 2020, 13, e00450. [CrossRef]

12. Silva, R.; de Brito, J.; Dhir, R. Use of recycled aggregates arising from construction and demolition waste in new construction applications. J. Clean. Prod. 2019, 236, 117629. [CrossRef]

13. Wang, Y.; Hughes, P.; Niu, H.; Fan, Y. A new method to improve the properties of recycled aggregate concrete: Composite addition of basalt fiber and nano-silica. J. Clean. Prod. 2019, 236, 117602. [CrossRef] 
14. Sánchez de Juán, M. Estudio Sobre la Utilización de Árido Reciclado Para la Fabricación de Hormigón Estructural. Ph.D. Thesis, Universidad Politécnica de Madrid, Madrid, Spain, 2004.

15. Proyecto GEAR. Guía Española de Áridos Reciclados Procedentes de Construcción y Demolición; Fueyo Editores: Madrid, Spain, 2012.

16. Vegas, I.; Azkarate, I.; Juarrero, A.; Frías, M. Diseño y prestaciones de morteros de albañilería elaborados con áridos reciclados procedentes de escombro de hormigón. Mater. Constr. 2009, 59, 5-18. [CrossRef]

17. Morón, C.; Ferrández, D.; Saiz, P.; Yedra, E. Measuring system of capillary rising damp in cement mortars. Measurement 2019, 135, 252-259. [CrossRef]

18. Thomas, C.; Cimentada, A.I.; Polanco, J.; Setién, J.; Méndez, D.; Rico, J. Influence of recycled aggregates containing sulphur on properties of recycled aggregate mortar and concrete. Compos. Part B Eng. 2013, 45, 474-485. [CrossRef]

19. Wang, Y.; Deng, Z.; Xiao, J.; Li, T.; Li, J. Mechanical properties of recycled aggregate concrete under compression-shear stress state. Constr. Build. Mater. 2021, 271, 121894. [CrossRef]

20. Parra, J.L.; Astudillo, B.; Carretón, R.; Castilla, J.; Sanabria, C.M.; Antuña, E. Áridos reciclados para hormigones y morte-ros. Boletín Geológico y Minero. Bol. Geológico Y Min. 2006, 117, 763-772.

21. Saiz-Martínez, P.; Ferrández-Vega, D.; Morón-Fernández, C.; De Tejada-Alonso, A.P. Comparative study of the influence of three types of fibre in the shrinkage of recycled mortar. Mater. Constr. 2018, 68, 168. [CrossRef]

22. Martínez, P.S.; Cortina, M.G.; Martínez, F.F.; Sánchez, A.R. Comparative study of three types of fine recycled aggregates from construction and demolition waste $(\mathrm{CDW})$, and their use in masonry mortar fabrication. J. Clean. Prod. 2016, 118, 162-169. [CrossRef]

23. Reis, G.; Quattrone, M.; Ambrós, W.; Cazacliu, B.G.; Sampaio, C.H. Current Applications of Recycled Aggregates from Construction and Demolition: A Review. Materials 2021, 14, 1700. [CrossRef] [PubMed]

24. Liu, Q.; Xiao, J.; Singh, A. Plastic Shrinkage and Cracking Behavior of Mortar Containing Recycled Sand from Aerated Blocks and Clay Bricks. Sustainability 2021, 13, 1096. [CrossRef]

25. Ferrández, D.; Saiz, P.; Morón, C.; Díaz, J.P. Estudio del comportamiento de los morteros reciclados frente al ruido de impacto. Inf. Constr. 2019, 71, 292. [CrossRef]

26. Sáiz Martínez, P. Utilización de Arenas Procedentes de Residuos de Construcción y Demolición, RCD, en la Fabricación de Morteros de Albañilería. Ph.D. Thesis, Universidad Politécnica de Madrid, Madrid, Spain, 2015.

27. Barrios, A.M.; Vega, D.F.; Martínez, P.S.; Atanes-Sánchez, E.; Fernández, C.M. Study of the properties of lime and cement mortars made from recycled ceramic aggregate and reinforced with fibers. J. Build. Eng. 2021, 35, 102097. [CrossRef]

28. Yu, Z.; Zhao, Y.; Ba, H.; Liu, M. Synergistic effects of ettringite-based expansive agent and polypropylene fiber on early-age anti-shrinkage and anti-cracking properties of mortars. J. Build. Eng. 2021, 39, 102275. [CrossRef]

29. Puertas, P.; Amat, T.; Vázquez, T. Comportamiento de morteros de cementos alcalinos reforzados con fibras acrílicas y de polipropileno. Mater. Constr. 2000, 50, 69-84. [CrossRef]

30. Mesbah, H.; Buyle-Bodin, F. Efficiency of polypropylene and metallic fibres on control of shrinkage and cracking of recycled aggregate mortars. Constr. Build. Mater. 1999, 13, 439-447. [CrossRef]

31. Rajaei, S.; Shoaei, P.; Shariati, M.; Ameri, F.; Musaeei, H.R.; Behforouz, B.; de Brito, J. Rubberized alkali-activated slag mortar reinforced with polypropylene fibres for application in lightweight thermal insulating materials. Constr. Build. Mater. 2021, 270, 121430. [CrossRef]

32. Alberti, M.G.; Diaz, A.E.; Ruiz, J.G.; Alvarez, C.; Iranzo, A.P. Moderate-strength concrete reinforced with polyolefin fibres: Considerations and design of a competitive structural concrete. DYNA Ing. E Ind. 2020, 95, 322-326. [CrossRef]

33. Colangelo, F.; Cioffi, R.; Liguori, B.; Iucolano, F. Recycled polyolefins waste as aggregates for lightweight concrete. Compos. Part $B$ Eng. 2016, 106, 234-241. [CrossRef]

34. Slebi-Acevedo, C.J.; Lastra-González, P.; Castro-Fresno, D.; Bueno, M. An experimental laboratory study of fiber-reinforced asphalt mortars with polyolefin-aramid and polyacrylonitrile fibers. Constr. Build. Mater. 2020, 248, 118622. [CrossRef]

35. Cascardi, A.; Leone, M.; Aiello, M.A. Transversal joining of multi-leaf masonry through different types of connector: Experimental and theoretical investigation. Constr. Build. Mater. 2020, 265, 120733. [CrossRef]

36. Cement Permanent Commission. Instruction for the Receipt of Cement RC-08; Ministry of Public Works and Transport: Madrid, Spain, 2008.

37. UNE 80103. Test Methods of Cements. Physical Analysis. Actual Density Determination; Aenor International: Madrid, Spain, 2013.

38. UNE-EN 933-2. Tests to Determine the Geometric Properties of Aggregates_Part 2: Determination of Particle Size: Test Sieves, Nominal Size of Openings; Aenor International: Madrid, Spain, 1999.

39. NBE FL-90. Norma Básica de Edificación. In Muros Resistentes de Fábrica de Ladrillo; BOE-A-1991-157; Ministerio de Obras Públicas y Urbanismo: Madrid, Spain, 1991.

40. Nedeljković, M.; Visser, J.; Šavija, B.; Valcke, S.; Schlangen, E. Use of fine recycled concrete aggregates in concrete: A critical review. J. Build. Eng. 2021, 38, 102196. [CrossRef]

41. UNE-EN 13139. Aggregates for Mortar; Aenor International: Madrid, Spain, 2003.

42. UNE-EN 933-1. Tests for Geometrical Properties of Aggregates—Part 1: Determination of Particle Size Distribution—Sieving Method; Aenor International: Madrid, Spain, 2002.

43. UNE-EN 146404. Aggregates for Concrete. Determination of the Coefficient of Friability of the Sands; Aenor International: Madrid, Spain, 2018. 
44. UNE-EN 1097-3. Tests for Mechanical and Physical Properties of Aggregates_Part 3: Determination of Loose Bulk Density and Voids; Aenor International: Madrid, Spain, 1999.

45. UNE-EN 1097-6. Tests for Mechanical and Physical Properties of Aggregates_Part 6: Determination of Particle Density and Water Absorption; Aenor International: Madrid, Spain, 2014.

46. Martínez, I.; Etxeberria, M.; Pavón, E.; Díaz, N. A comparative analysis of the properties of recycled and natural aggregate in masonry mortars. Constr. Build. Mater. 2013, 49, 384-392. [CrossRef]

47. Yedra, E.; Ferrández, D.; Morón, C.; Gómez, E. New System to Determine the Evolution of the Dynamic Young's Modulus from Early Ages in Masonry Mortars. Appl. Sci. 2020, 10, 8129. [CrossRef]

48. Ulsen, C.; Kahn, H.; Hawlitschek, G.; Masini, E.; Angulo, S.; John, V. Production of recycled sand from construction and demolition waste. Constr. Build. Mater. 2013, 40, 1168-1173. [CrossRef]

49. Ferrández, D.; Saiz, P.; Morón, C.; Dorado, M.; Morón, A. Inductive method for the orientation of steel fibers in recycled mortars. Constr. Build. Mater. 2019, 222, 243-253. [CrossRef]

50. SikaFiber. Hoja de Datos Técnica; Sika: Baar, Spain, 2019.

51. García, A.B. Morteros con Propiedades Mejoradas de Ductilidad por Adición de Fibras de Vidrio, Carbono y Basalto. Ph.D. Thesis, Universidad Politecnica de Madrid, Madrid, Spain, 2019.

52. Saiz-Martínez, P.; González-Cortina, M.; Martinez, F.F. Characterization and influence of fine recycled aggregates on masonry mortars properties. Mater. Constr. 2015, 65. [CrossRef]

53. Spanish Ministry of Public Works. Instrucción de Hormigón Estructural EHE-08 (Spanish Structural Concrete Code). BOE 2008, 203, 35176-35178.

54. Álvarez, M.; Ferrández, D.; Morón, C.; Atanes-Sánchez, E. Characterization of a New Lightened Gypsum-Based Material Reinforced with Fibers. Materials 2021, 14, 1203. [CrossRef] [PubMed]

55. UNE-EN 1015-2: 2007. Methods of Test for Mortar for Masonry_Part 2: Bulk Sampling of Mortars and Preparation of Test Mortars; Aenor International: Madrid, Spain, 2007.

56. Ramírez, C.P.; Sánchez, E.A.; Merino, M.D.R.; Arrebola, C.V.; Barriguete, A.V. Feasibility of the use of mineral wool fibres recovered from $\mathrm{CDW}$ for the reinforcement of conglomerates by study of their porosity. Constr. Build. Mater. 2018, 191, 460-468. [CrossRef]

57. UNE-EN 1015-11:2000/A1:2007. Methods of Test for Mortar for Masonry_Part 11: Determination of Flexural and Compressive Strength of Hardened Mortar; Aenor International: Madrid, Spain, 2007.

58. UNE-EN 1015-18:2003. Methods of Test for Mortar for Masonry-Part 18: Determination of Water Absorption Coefficient Due to Capillary Action of Hardened Mortar; Aenor International: Madrid, Spain, 2003.

59. UNE-EN 1015-10:2000. Methods of Test for Mortar for Masonry_Part 10: Determination of Dry Bulk Density of Hardened Mortar; Aenor International: Madrid, Spain, 2000.

60. UNE-EN 1015-12:2016. Methods of Test for Mortar for Masonry_Part 12: Determination of Adhesive Strength of Hardened Rendering and Plastering Mortars on Substrates; Aenor International: Madrid, Spain, 2016.

61. UNE 80-112-89. Test Methods. Cement. Determination of Shrinkage and Swelling in Water; Aenor International: Madrid, Spain, 1989.

62. Karimipour, A.; Ghalehnovi, M. Comparison of the effect of the steel and polypropylene fibers on the flexural behaviour of recycled aggregate concrete beams. Structures 2021, 29, 129-146. [CrossRef]

63. Garcia, A.B.; Escamilla, A.C.; Yunta, F.G.; Fernandez, M.E.M. Influence of fibers addittion on the properties of hydraulic lime based mortars. DYNA Ing. E Ind. 2018, 93, 228-232. [CrossRef]

64. Yao, W.; Li, Z. Flexural behavior of bamboo-fiber-reinforced mortar laminates. Cem. Concr. Res. 2003, 33, 15-19. [CrossRef]

65. Martín-del-Río, J.J. Estudio del Comportamiento Durable de Pastas y Morteros de Cemento en Condiciones de Agresividad. Ph.D. Thesis, Universidad de Sevilla, Sevila, Spain, 2004.

66. Morón, C.; Saiz, P.; Ferrández, D.; García-Fuentevilla, L. New System of Shrinkage Measurement through Cement Mortars Drying. Sensors 2017, 17, 522. [CrossRef] [PubMed] 